\title{
SEISMIC AFTERSHOCKS AND LANGUAGE POLICY IN OAXACA, MEXICO: A COLLABORATIVE ACCOUNT OF RESOLVE AND RESISTANCE IN TEACHERS' DEFENSE AND USE OF ORIGINAL ${ }^{1}$ LANGUAGES
}

\author{
Beatriz Gutiérrez Luís \\ Vicente Guerrero Bilingual Preschool, Oaxaca, Mexico \\ Gisela Baloes Gutiérrez \\ Vicente Guerrero Bilingual Preschool, Oaxaca, Mexico \\ Mayem Arellanes Cano \\ Technical Middle School \#14, Oaxaca, Mexico
}

Lois M. Meyer ${ }^{2}$

University of New Mexico, USA

\begin{abstract}
Since 2013, Oaxacan Indigenous educators have experienced "seismic aftershocks" from three tumultuous developments: the massive 8.2 earthquake in September 2017 along Oaxaca's Pacific coast, immediately followed by other earthquakes and continuing tremors; homogenizing federal education reforms imposed since 2013, including the projected closure of 100,000 rural schools and elimination of pedagogical preparation for teachers; and the surprise election of Andrés Manuel López Obrador, called the first leftist Mexican president in decades. In this article, Indigenous teachers and their U.S. colleague collaboratively narrate and analyze two case studies of efforts in specific Oaxacan schools to defend and promote original language use and Indigenous pride, despite earthquake damage to school structures and repression and political abandonment by federal and state governments. A final reflection by a Native American educator places the Oaxacan findings into the wider context of defense of Indigenous rights in the face of cultural and linguistic genocide.
\end{abstract}

Keywords: Indigenous education; Original languages; Mexico; bilingual education

\footnotetext{
1 "Original language" rather than "Indigenous language" is the preferred usage in Mexico and often in other parts of Latin America.

${ }^{2}$ Correspondence: Lois M. Meyer, Dept. of Language, Literacy \& Sociocultural Studies, Hokona-Zuni Hall, Rm. 140, MSC 05 3040, 1 University of New Mexico, Albuquerque, NM 87131-0111. Email: 1smeyer@unm.edu
} 
Introduction: Indigenous Teachers' Work in the Complex Seismic Context of Language Policy in Oaxaca (Lois M. Meyer, U.S. applied linguist and bilingual educator)

Shifting tectonic plates under and around Mexico's land mass make this U.S. neighbor highly prone to earthquakes, particularly in the state of Oaxaca, situated along Mexico's southern Pacific coast and home to its greatest Indigenous population. In September 2017, much of this coastal and isthmus region, populated heavily by Zapotecs and also Ikoots communities such as San Mateo del Mar, experienced three destructive earthquakes in three weeks' time, usually with epicenters in the seismic cauldron of the Gulf of Tehuantepec. The first, centered in Chiapas only kilometers southeast of the Oaxacan coast, struck with a magnitude 8.2 on September 7, the largest earthquake in Mexico in a century. The damage across the region was sobering:

The dimension of the disaster is clear in its statistics: 180,000 people affected, 60,600 homes damaged or destroyed, 82 dead, 3,476 schools deteriorated. However, if the tragedy is measured by the consequences of these impacts, since that day this region is living a humanitarian crisis of enormous dimensions (Ignacio, 2017).

Days later, on September 19, 2017, another quake of 7.1 magnitude hit the same region. Then on September 23, an earthquake of 6.1 magnitude hit the Isthmus of Tehuantepec in Oaxaca, with its epicenter in the community of Matías Romero. Tremors and aftershocks continue to this day, gravely affecting the economy, daily life, and education in San Mateo del Mar and other severely damaged communities (Snyder, 2017).

Still, geological earthquakes are not the only convulsions to shock and confound Oaxaca in recent years. The purpose of this paper is to narrate from diverse personal and scholarly perspectives the profound "seismic aftershocks" caused by educational and political upheavals, as well as geological ruptures, affecting the use and defense of Indigenous languages in rural Oaxacan schools and communities. We tell our story collaboratively, identifying each individual voice: three local Oaxacan Indigenous teachers (Beatriz Gutiérrez Luís, Gisela Baloes Gutiérrez, and Mayem Arellanes Cano), who each recount their lived experiences of creative and courageous struggle in two different rural school settings, stories which I, a U.S. applied linguist, bilingual educator, and their close colleague across two decades, contextualize and translate to English for international readers. We include an invited final reflection by Hayes Lewis, Native American educator and former Superintendent of Schools in Zuni Pueblo, New Mexico.

Our multi-voiced format merits explanation. While all four authors are women, each of us writing out of her own experience and perspective, we do not consider this either a gendered or individualized analysis of Oaxacan resolve and resistance. In both school contexts documented here, the instructional challenges are faced by female and male teacher colleagues alike, who collectively implement creative instructional changes as they confront often extreme external circumstances. Nor is this study a traditional narrative inquiry: Beatriz, Gisela and Mayem each narrate their own stories in their own words, yet each account was constructed as we sat together for hours, listening carefully to each other's memories, prodding one another to resurrect poignant details, and jointly crafting our collective text. Nor do I, the sole university academic and English speaker among us, function as an external analyst of the Oaxacan teachers' case studies. Rather, through our intensely focused conversations across hours and days, together we were able to finally 
discern, and then name, the pervasive and problematic influences on their teaching work that needed to be highlighted within and across their stories; that is, through our collective reflection the defining importance of the three sociopolitical "seismic aftershocks" that have massively affected the details of these teachers' personal and pedagogical lives revealed themselves.

Beyond phenomenology, this study is influenced heavily by Garfinkel's ethnomethodology (Garfinkel 1967, 2002; Heritage 1984), a radical branch of sociology which understands human action (here, the teachers' pedagogical practices), not as theorydriven professional scripts or research-based best practices, but rather as "common-sense knowledge-in-action," what Garfinkel called the wisdom of everyday, yet contingent, "lived work." The teachers' accounts witness to their profound knowledge of their communities, their school contexts, their years of professional experience, and their passionate defense of their Indigenous identity, which together embolden them to confront with resolve the uncertain, pressured and constantly shifting circumstances of their daily teaching challenges and the precariousness of their community's language and culture realities. Importantly, they address these challenges not as superhuman cultural heroines, but rather as Indigenous teachers who carry out the "ordinary" teaching work, together with colleagues and community members, that their local, particular, even extraordinary, school circumstances call forth.

\section{Research Goal}

Given the profoundly local and grounded nature of an ethnomethodological study, we began not with questions, but with a goal. We sought to document and analyze the daily "lived work" of Beatriz, Gisela and Mayem in their unique school and community contexts, with particular attention to their efforts to support and sustain the original languages and cultures of their students. How did they do this? What were the pressures they had to contend with in each context in order to accomplish this work? What did "resolve" and "resistance" look like as everyday, unavoidable elements of their teaching? We knew that Mexico's recent, complicated political and economic context was a pervasive backdrop to their teaching and therefore to our study, especially including three prominent historical developments: a) constitutional amendments mandating drastic education reforms, representing neoliberal policies that exacerbated the poverty and marginalization of their communities; b) the 2017 earthquakes; and c) the stunning election in 2018 of a reportedly "left-leaning" Mexican president. Our goal was to document how teaching's work prioritizing language and culture resilience was carried out, not by means of special programs or external experts, but by these very teachers as they went about their teaching work in their specific contexts. And if their work was hampered or impeded, we wanted to see what "resolve" and "resistance" against such barriers could look like as a local, daily pedagogical achievement.

\section{Seismic Aftershock of the Education Reforms}

In 2013, only a few years before the 2017 earthquake devastation in rural Oaxaca, Mexico's ruling Institutional Revolutionary Party (PRI) orchestrated expansive reforms to the Mexican Constitution, with particular focus on education. One aspect of these reforms was the government's intention to massively restructure public education by closing down 100,000 rural, multi-grade schools nationwide (Hernández Navarro, 2016). The affected students were to be removed from their communities and concentrated in larger and arguably better-equipped regional "complete" schools, that is, schools without combined 
grades often located considerable distances from the children's homes and communities. Predictable but officially unacknowledged consequences of such a plan would be: a decrease in children's contact with their community cultures and languages, such as Mazatec, Mixtec or Chinantec; massive reduction in the teacher population as grade level enrollments in concentrated schools would be allowed to increase; disruption of teachers' ties with children's homes and communities; an end to the last vestiges of the Mexican Rural School movement ${ }^{3}$; and a hastening of the neocolonial process of depopulating rural communities so that their natural resources (water, wind, metals, agricultural lands, etc.) can be taken over by commercial interests (Rockwell \& Garay-Molina, 2014; Soberanes Bojórquez, 2017; Para reconsiderar la estrategia "reconcentración de escuela, 2016).

The reforms to the General Law of Education were met with tenacious civic and teacher union resistance, especially in Oaxaca. According to Section 22, Oaxaca's powerful dissident branch of the National Union of Education Workers (SNTE) and one of the leaders of the union's democratizing arm, the National Coordinator of Education Workers (CNTE), these top-down federal reforms, far from promoting educational equity and cultural relevance, were a governmental move to privatize public education, with consequences that are pervasive and debilitating, not only for teachers, but for Mexican society as a whole, and especially for impoverished Indigenous communities (Meyer, 2017).

The risks posed by the education reforms to Indigenous communities are varied and profound, including negative impacts on the maintenance or revitalization of original languages. While Spanish is the de facto official language of the government and the first language of about 90 per cent of the Mexican population, Mexico has the largest population of Indigenous language speakers and the highest linguistic diversity in the Americas, with 68 recognized Amerindian languages classified in eight linguistic families and fifteen subfamilies (Terborg et al., as cited in Vázquez Carranza, 2009; original language count updated in Mioli \& Higuera, 2016). Despite this diversity, it was only in 1992 that Article 4 of the Constitution recognized Mexico's multilingual and multicultural character as a cultural heritage of the nation (Vázquez Carranza, 2009). Then in March 2003, Mexico recognized Indigenous languages along with Spanish as national languages (Mioli \& Higuera, 2016). Still, recognition of Mexico's linguistic diversity, while enshrined in the Constitution, is little more than official rhetoric that rarely is implemented in practice. The Secretariat of Public Education (SEP), Mexico's federal education entity that centralizes most decisions about the instructional content taught in public schools nationwide, oversees implementation of the recent education reforms that rigorously pursue an accelerating agenda of homogenization and standardization in the preparation and evaluation of both students and teachers, under the banner of global competitiveness and "increased opportunities for all." The result is a restricted and standardized national curriculum that largely ignores the histories, social contexts, languages, and learning needs of students in Indigenous communities (Meyer, 2017).

\section{Seismic Aftershock of the 2018 Presidential Election}

A third "seismic aftershock" rocked Mexico in the aftermath of the July 1, 2018, presidential elections - after multiple decades of right-wing, government-controlled and widely denounced corrupt elections, Andrés Manuel López Obrador (AMLO) swept not

\footnotetext{
${ }^{3}$ Schoenhals (1964) states, "One of the most significant outgrowths of the Mexican revolution was the educational reforms" (p. 42). Furthermore, "[ $\mathrm{t}]$ he heart of the revolutionary program of education was the rural school" whose basic premise was that "education is a community project for adults, young people, and children” (pp. 33-34).
} 
only the presidential contest, but all levels of the national election. Consequently, when he assumed power on December 1, 2018, AMLO became the "first leftist to govern in decades" (Partlow, 2018).

It is hard to describe Mexico's shock and pride at AMLO's "stunning landslide victory" (Wood et al., 2018), a shock reportedly shared by the victorious candidate himself. "We will respect everyone," he has said. "But we will give preference to the most humble and forgotten" (Partlow, 2018). During his campaign, AMLO promised to stabilize and grow the economy, address rising violence and organized crime, stem government corruption through his own example of honest leadership, deal with Trumpian volatility in Mexico/US relations, and review and revise the oil and gas contracts and the education reform (Wood et al., 2018).

Significantly, part of the platform of AMLO's party, MORENA, stated:

The National Regeneration Movement (MORENA) is fighting for the right of Indigenous peoples not to be discriminated against; the right to cultural integrity; the rights of possession, use, control and access to their lands and resources; the right to social development and wellbeing, and the rights of political participation and free, prior and informed consent (Programa del Movimiento Regeneración Nacional, undated).

This litany of rights promised to Indigenous communities reflects a contentious history, according to Beatriz Gutiérrez Luís. For years Indigenous Peoples were nonexistent in Mexican law and government legislation. With the uprising in Chiapas in 1994 of the Zapatista Army of National Liberation (known as the EZLN or the Zapatistas) this changed; the Mexican Constitution was reformed to recognize the cultural diversity of Mexico's Indigenous Peoples. However, two years prior, Article 27 of the Mexican Constitution was rewritten to legalize the pillaging of Mexico's natural resources, even those located within communal lands belonging by law to Original Peoples since the Mexican Revolution (Kelly, 1994). According to Beatriz, this began the expropriation of natural resources that intensified in years following and continues today, with commercial interests taking possession (or attempting to) of mining, wind and hydroelectric resources on communally controlled lands. The government of Peña Nieto (2012-2018) privatized what remained of government controlled public resources, among them education, health, oil and gas.

Despite AMLO's campaign promises, the deeply communal EZLN denies that the newly elected president is a leftist reformer, seeing him instead as a moderate rightist at best. In a widely circulated public communique immediately following the July 1 election, Zapatista spokesperson Subcomandante Galeano (formerly Marcos) announced the EZLN's stand that nothing is likely to change with the new administration: "They can change the foreman and middle management, but the owner of the finca is still the same" (Mandujano, 2018).

Various Indigenous educators and activists in Oaxaca have described their reaction to Mexico's historic 2018 election as “cautious optimism." Beatriz expressed the hope that "this government will change the direction of what has been the policy of those who have governed this country." Yet, despite AMLO's commitment to the "most humble and forgotten" and his party's promises to respect Indigenous cultural, economic and political rights, AMLO has imposed megaprojects such as the Maya Train and the TransIsthmus Corridor in Mexico's southeast, and has been silent regarding a language policy that 
addresses protection of original languages. Each day more languages become extinct and there is no program that promotes maintenance of original languages by their speakers or the learning of these as second languages (Wood et al., 2018).

In this article we describe the seismic aftershocks and reverberations in Indigenous language education in specific rural communities of Oaxaca following the three tumultuous eruptions in Mexican life described above: a) the destructive earthquakes of September 2017 ; b) the imposed education reforms of 2013; and, c) the unanticipated presidential election of López Obrador in July 2018. Beatriz Gutiérrez Luís, preschool director, and Gisela Baloes Gutiérrez, teacher of 5-year-olds in the Vicente Guerrero Bilingual Preschool located in the Ikoots coastal community of San Mateo del Mar, describe the firm resolve of teachers and parents to rebuild both their earthquake demolished classrooms and their maintenance bilingual program. Movingly, they describe their unflinching resolve to turn the devastating earthquakes into learning opportunities that enrich the Ombeayiüts language experience of students and teachers alike, despite financial and political abandonment by state and federal education authorities. Mayem Arellanes Cano, Zapotec lawyer and Social Sciences teacher at Technical Middle School \#14 Reyes Mantecón Boarding School in the municipality of San Bartolo Coyotepec, narrates her efforts to encourage Indigenous pride and original language use among middle school boarders who are speakers of 10 of Oaxaca's original languages and variants. She initiated a creative curricular project, Your Language, My Language, Our Languages, the first such curricular effort focused on Indigenous languages in the school's 50-year history. Though the school sustained only minimal structural damage from the September 2017 earthquakes, Mayem describes the resolve and resilience required to initiate her language program in the face of seismic aftershocks that rumbled throughout Oaxaca's teacher ranks following repressive middle school federal and state education reforms, and the generational trauma and shame expressed by students toward their own and their peers' Indigenous language competence. I, Lois M. Meyer, am a U.S. professor, applied linguist, bilingual educator, and close collaborator for 20 years with the other three co-authors and with the affiliated statewide school district, Plan Piloto - Coalition of Indigenous Teachers and Promoters of Oaxaca (Plan Piloto-CMPIO) on community-based Indigenous bilingual education and teacher professional development. My roles in this collaborative article were to facilitate our collective analysis of both the context and consequences of the three seismic upheavals in Mexico as these affect Oaxacan language policy and pedagogy, and as the sole English speaker, to translate all cited Spanish language sources and to help craft and translate the case study narratives drafted by the Oaxacan co-authors. I also invited the closing reflection by Hayes Lewis, Native American educator and activist from Zuni Pueblo in New Mexico and former Superintendent of the Zuni Public Schools, whose reflection enriches the Oaxacan account with an international Indigenous perspective.

\section{A. Seismic Aftershocks and Language Policy in San Mateo del Mar: The Case of the Vicente Guerrero Bilingual Preschool (Beatriz Gutiérrez Luís, Ikoots preschool director, and Gisela Baloes Gutiérrez, Ikoots preschool teacher of 5-year-olds at Vicente Guerrero Bilingual Preschool in San Mateo del Mar)}

Beatriz: We, the Ikoots people of San Mateo del Mar, inhabit our ancestral lands on the south Pacific coast of the Mexican state of Oaxaca, on a narrow isthmus surrounded by the Pacific Ocean on the south and a giant inland lagoon to the north, called the Tileme or Dead Sea. During the months of October through March, our coastal region is swept by powerful northern winds, which is why transnational companies eye our lands with jealous 
envy. Arguing their need to respond to the demand for electricity produced by clean energy, these companies want to strip us of our traditional fishing coast in order to install commercial wind energy turbines. We have struggled hard to keep them out, a fight we continue to this day.

San Mateo del Mar has a population of nearly 15,000 inhabitants, 70 percent of whom dedicate themselves to fishing. From the ocean we harvest shrimp, crabs, and a variety of fish such as white mojarra and catfish, employing nets that are hoisted far offshore by wind-propelled kites and then dropped into deeper waters in search of a better haul. Small hand-carved cayuco boats transport the fishermen out to the nets to bring in the daily catch. Still, fishing does not guarantee that there will be food on the table at the end of the day. At times the nets are pulled up empty because there are no fish, such as when the lagoon dries up from lack of rain, or after the devastating earthquakes and tidal waves in September 2017, when for three months the fish and shrimp fled our coast for deeper waters. Those in our community who are not fishermen (about 30\%) are involved in activities such as small businesses, handcrafts and agriculture.

\section{Linguistic Realities of San Mateo del Mar}

Beatriz: Our word, our spoken tongue, is Ombeayiüts, though the catalog of languages maintained by Mexico's National Institute of Indigenous Languages (INALI) calls our language "Huave" (Instituto Nacional de Lenguas Indígenas, 2012). For us, this term is demeaning; for the same reason we say Ikoots, not "Huave," when we refer to ourselves and to our culture.

Ombeayiüts, a language isolate, is unrelated to any of the other 67 Indigenous languages spoken in Mexico and, like many others, is in danger of extinction. There are four Ikoots communities, but the municipality of San Mateo del Mar has the most Indigenous language speakers. In the other three communities (San Francisco del Mar, San Dionisio del Mar, and Santa María del Mar), very few children speak Ombeayiüts, a clear sign of language loss. In contrast, of the 120 youngsters enrolled in Vicente Guerrero Bilingual Preschool in May 2017, 85 spoke our original language, while 35 were monolingual in Spanish. Yes, in our community there is language loss, but we are fighting to reverse this negative linguistic tide.

\section{Antecedents}

Beatriz: Vicente Guerrero Bilingual Preschool opened its doors to the San Mateo del Mar community in 1974 as a Spanish Language Instruction Center (Centro de Castellanización) intended for children 3 to 5 years old who were speakers of the Ombeayiüts language. Castellanización, the official government policy at the time (Granja Castro, 2010), set out to impose Spanish as the only national language and to eliminate the multiple Indigenous languages and cultures of the nation, a policy of extermination directed against the original inhabitants and true owners of this country. For approximately 20 years, the Vicente Guerrero teachers, all native Ikoots and proficient Ombeayiüts speakers, were employed by the federal government as instruments of its policy to "convert" our villagers into Spanish language speakers.

The emergence of the Zapatista Army of National Liberation (EZLN) in 1994 in the neighboring state of Chiapas had profound impacts in Oaxaca and in our communities. In following years, the Coalition of Indigenous Teachers and Promoters of Oaxaca (CMPIO), of which we are a part, initiated a Pedagogical Movement to unite efforts by fathers, mothers, teachers, children, local village authorities, and collaborating academics, with the 
shared goal to promote educational alternatives that respond to the necessities and interests of Oaxaca's Indigenous children and rural communities. Through our participation in the Pedagogical Movement and with its support, we were able to abandon "castellanización" and construct instead an alternative, community-based education at our preschool, one that prioritized the Pedagogical Movement's first guiding principle: develop and strengthen the Indigenous languages and cultures. About 15 years ago we informed parents about different models of bilingual education, then we deliberated collectively until we reached agreement that we would use Ombeayiüts as the primary language of instruction while also introducing Spanish as a second language.

Today 70 percent of Vicente Guerrero preschoolers speak our original language while 30 percent are primary speakers of Spanish. We conduct our bilingual classes 60 percent of the time in Ombeayiüts and 40 percent in Spanish, keeping the languages separate rather than mixing their use in the same block of instructional time. Our preschoolers are so young that they cannot always distinguish one language from the other so we aid them by separating our use of the two languages and signaling when we change between languages, using symbols appropriate for each culture (e.g. blowing a conch shell when it is time to speak only Ombeayiüts, and lighting a candle when it is time to switch to only Spanish). In our school we work hard to strengthen and develop our original language, creatively using our own community wisdom and linguistic resources to appropriately teach the children to distinguish different flavors, smells, shapes, sizes, colors, and textures, and to describe cultural topics such as fishing practices, corn fields and planting, gastronomy, flowers, fruits, animals, beverages, traditional games, our local climate, our homes, and our fiestas. Basing our learning experiences on local cultural topics entices the children to appropriate the unique cultural and linguistic knowledge of our community, so that they learn to value and respect the environment and all that we hold sacred.

\section{Community-based Bilingual Instructional Practices}

Gisela: When I develop an instructional theme with my 5-year-old students, everything revolves around the months of the year, the seasons, or community happenings. For example, the children learn the months for planting or for collecting fruits that are native to our community. They learn to identify the flower of the plant, and the fruit itself, its taste, its smell, texture, size and shape, its unique characteristics. This involves a complex linguistic and learning process for the children, as Ombeauyiüts has many semantic distinctions that are not present in Spanish; for example, in San Mateo there are 13 different words to describe distinct flavors.

Beatriz: The children learn about climate by delving into the principal activity of our community, which is fishing. We investigate how this activity is related to weather and our rainy and windy seasons. But we don't just talk about fishing - we observe, smell and touch it! Accompanied by parents, we walk to the ocean where we collect snails, clams, shellfish, and other treasures. But before touching the sacred things of the ocean, we remind the children to respect and greet the sea, and to ask permission to spend some time in its presence, playing traditional games on the beach.

While at the ocean's edge, we watch the men - the children's fathers, uncles and grandfathers - as they manipulate the fishing nets and the kites that hoist the nets out to sea, and as they row their cayuco boats out to bring in the daily catch. On the beach the children draw figures and letters in the sand with sticks, which is one way we revitalize teachings done by the grandparents, who traditionally illustrate their oral storytelling with sand drawings. As teachers, we always look for opportunities to display the value of early 
reading by reproducing it in community spaces, giving the children the opportunity to experience learning in public and tactile ways in direct contact with sand and earth. The participation and collaboration of parents and grandparents throughout this experiential process of constructing learning - being together, expressing opinions, observing, sharing, stretching the children's use of Ombeayiüts in new directions - is tremendously valuable.

Upon returning to the classroom, the children continue learning about the different tools and equipment used for fishing, such as nets, kites, cayuco boats, and fishing baskets. All the shells and other treasures we have collected on the beach are carried back to the classroom and turned into learning materials to be counted, organized, described and compared by size, shape, color and texture.

Through this outdoor class, the children gain a general panorama of knowledge about our lagoon and the ocean. They create a mural where they distinguish freshwater fish from ocean fish, and those that are edible from those that are not. The theme of fishing that we began with the trip to the ocean lasts about a month and is reinforced through many different activities related to this theme.

When addressing significant community themes, we women are permitted to teach even gender-specific cultural practices we would not otherwise engage in outside the classroom. In the past, the belief was that women would harm the water if they fished or touched the net, but in our preschool both male and female teachers are permitted to reinforce in the children the local wisdom about fishing, using fishing tools as instructional aids.

Creating our own books with text in Ombeayiüts about all our community-based themes and excursions has greatly enriched our Indigenous language instruction. Often these books are created collaboratively by teachers and parents and shared among our classrooms, where we read them aloud and then make them available to the children to page through and enjoy.

The children display what they are learning by painting murals on the walls of the school, reflecting our community context. Prior to the devastating earthquake on September 7, 2017, the walls of Vicente Guerrero Bilingual Preschool were colorfully adorned with children's paintings, carefully lettered in both Ombeayiüts and Spanish. Sadly, that day's flooding and destruction left the preschool structurally unusable, our bilingual books and teaching materials destroyed, and the beautifully adorned walls were shattered beyond repair.

Seismic Aftershocks and the School Structure after the Earthquake (September 2017)

Gisela: The earthquakes and consequent flooding largely decimated our school. Four of our preschool's five classrooms were declared unusable by government inspectors and sealed. Six weeks went by before the dangerously damaged classrooms and perimeter wall finally were leveled by volunteers - the children's fathers - since the promised government assistance never materialized.

We teachers held class on the concrete school patio to try to regain some sense of normalcy for the children despite the destruction visible everywhere in the village. Hundreds of homes were damaged, including those of many children and teachers, and potable water was scarce because the ocean, roiled by tectonic movements, had inundated our wells and contaminated our drinking water.

\section{Seismic Aftershocks and the Curriculum after the Earthquake}


Gisela: Early in each new school year my students and I engage the topic, "Our Homes," but the terrifying earthquake events we experienced in September 2017 massively transformed where and how we addressed this topic. Of course, we could not avoid talking about the physical and emotional trauma the children had experienced in their homes. But now talk about "our homes" was much different than it had been in any previous school year, for reasons both expected and unexpected. For example, I asked the children questions like the following:

Where were you when the earthquake happened?

Who were you with? What happened in your house?

What did you see? What did you feel?

Did you hear anything? What did you do?

The children's responses were detailed and complex, stretching both their Spanish and their Ombeayiüts language skills in order to pour out their traumatic emotional memories:

"I was in my house;" "My daddy wasn't home; he had gone fishing."

"My house fell;" "It flooded;" "It broke apart;" "It split open."

"The earth moved;" "It opened up;" "Trees moved and fell down;" "Dishes broke."

"My mommy says the ground cried out;" "It thundered;" "I heard so much noise."

"My head hurt;" "I felt dizzy."

"We hugged each other;" "Nobody could stand up;" "Everyone was crying."

Some children reported being awake when the earthquake struck, others were asleep. It happened at night; they didn't see anything; they bumped into things when they finally could get up and move around. They couldn't leave the house because the door was jammed; they were frightened; they had nowhere to sleep; they were in the street.

I had not anticipated the profound linguistic lessons the earthquake and its aftermath would bring, not only for these five-year-olds but also for me. I consider myself a fluent Ombeayiüts speaker, yet I sought out village elders to inquire how to express countless semantic distinctions in Ombeayiüts that we needed to describe the children's earthquake experiences and my own, words unfamiliar even to me because I had never before witnessed, or tried to describe, the destructive details of such a powerful earthquake.

The children and I learned and used new vocabulary in Ombeayiüts to describe the loss or damage to our homes: walls, rooms, roofs and entire homes had "tumbled," "fallen," "flooded," "shifted sideways," "split open," "fractured," "cracked," "been pounded" - all words in our original language that sensitively detail what the children had witnessed but previously could not have described. All of us were exposed to the subtleties and intricacies of our Ombeayiüts, how our language signals shape, animate vs. inanimate objects, compositional materials, and so on, through subtle distinctions of verb selection and grammatical form.

For example, the children indiscriminately used the term najmiük ("it fell”) to say that their house had fallen; this word is very general in that it can be used to say that any house, fabricated or made of palm, or for that matter any other object or person, had fallen. But the earthquake made this familiar, generic term completely inadequate - there was so much more to passionately say and describe! Community elder Sr. Pedro explained that 
teajkean ("it broke apart") means that part of the house fell, but only part of a house constructed of fabricated material, not palm; lijchiüw ajpot ("it fissured") means that it split but didn't fall; tsoyot tiüt ("it sank a lot") is past tense but tsotot tiüt (it was submerged but not a lot) means the submersion was less than that indicated by tsoyot tiüt; chajchaw tiüt is the sound of a house falling, no matter whether it is constructed of fabricated materials or palm; lejkeat omal, lejkean otüing ("to crack") indicates that a specific part of the house cracked, such as the roof or the wall.

Also unexpected were our learnings about the importance that our homes have in our spiritual world view: that the house itself is sacred, that we ache when each part of our home is damaged because to us our home is like our body, with feet, arms, shoulders, a nose, a mouth, and a face. We learned that our home must be oriented toward the winds that both soothe but also pound our coast. And we learned that there is a traditional way to live and sleep in our homes, that the "head" of the house should always be oriented to the east or north.

At a public talk carried out in our local Community Learning Center, collaborating architects who are specialists in earthquake relief and reconstruction reported that the sandy soil in our highly seismic zone cannot support extremely heavy construction, which meant we needed to improve or "repair" our soil to increase its sustainability before rebuilding. They also demonstrated alternative types of construction using mud to strengthen our soil. So, we teachers went in search of mud so that our preschool children could manipulate it and experiment with its use, especially when it was combined with the sap of a specific tree in our community.

In our bilingual classrooms, we have always prioritized the creation of a warm family environment that encourages confidence, play, freedom, joy, and above all, an environment without fear. However, today it is impossible to escape the constant anxiety about damaged homes, destroyed classrooms, no place to play or work or run or store the new learning materials we are continuously recreating.

\section{Resolve and Resistance: Vicente Guerrero Bilingual Preschool one year later (September 21, 2018)}

Beatriz: For now, and with much effort, we still conduct our 5 classes on the concrete school patio. From October 2017 to January 2018, the children's fathers spent 6 volunteer days demolishing by hand our badly damaged and dangerous classrooms and removing all the waste materials; the government contributed nothing. The government has not released any of the funds promised for school reconstruction; instead, it promotes a program that we reject, where commercial companies are contracted by the government to reconstruct schools as they see fit without community input, leaving the community indebted with a 25-year-plan to repay the "loan." In December 2017, we formally complained to the UN's National Commission on Human Rights about this devious arrangement.

Even without adequate classrooms, we try to move the children ahead, but some of them cry and others act out, and teachers' voices compete with one another in the confined patio space. The earthquake relief architects taught us the wisdom in our seismic region not only of repairing our sandy soil, but also of constructing with bamboo that shifts with the earth's tremors. Together with parents, we are volunteering our time and resources to construct a large meeting room of bamboo, and a non-governmental group is helping us supply it with instructional materials. Hopefully next week we will know exactly how many children we will serve this year, since the number has fluctuated. Some parents registered 
their children with us but now some of them do not want to give the volunteer time needed to help us rebuild (though the other preschool in our community requires reconstruction, too).

So, this is how things are now - despite relentless physical and governmental seismic aftershocks, and to the extent possible, we keep on keeping on. That is, while facing earthquakes, government apathy, and repressive education reforms, we resist. And we have some hope for better policies ahead under the new president. But come what may, we resolve to defend and expand the value and use of our original language into our future generations.

\section{B. Seismic Aftershocks and Language Policy in San Bartolo Coyotepec: The Case of Technical Middle School \# 14. ${ }^{4}$ Reyes Mantecón Boarding School (Mayem Arellanes Cano, Zapotec lawyer \& Social Sciences teacher)}

\section{Description \& Antecedents:}

Technical Middle School \#14, a boarding school where nearly two-thirds of the 402 students live, study, eat and relax on site, is located in the community of Reyes Mantecón, in the municipality of San Bartolo Coyotepec, Oaxaca, between the state's capital city, Oaxaca, and its southern coast. The school has been transformed across time by political winds: it opened in 1938 as a Practical School of Agriculture; was converted in 1960 into a normal school tasked with preparing rural teachers; was closed in 1968 along with 13 other rural normal schools due to their anti-government activism ${ }^{5}$; and reopened in 1969 as the Technological Agrarian Middle School No. 162, renewing its original focus on agricultural sciences and animal husbandry for $7^{\text {th }}$ through $9^{\text {th }}$ graders. Finally, in 1979, it became Technical Middle School No. 14, and today is one of only two middle schools in the State of Oaxaca that board students.

The students' curriculum is the same as in all the technical middle schools of the nation, including math, Spanish, biology, chemistry, history of Mexico, and a state subject matter, in this case the history and geography of Oaxaca, which I teach. All of these subjects are taught in the dominant language, Spanish. One distinguishing characteristic of this boarding school is its technical teachings about agriculture, cattle husbandry, beekeeping, and food commercialization, resulting from the school's focus on agricultural sciences. Another unique element is the program of after-school activities or clubs available to boarding school students, such as competitive wrestling (our students have competed and won medals in other states and even internationally in Cuba and Russia), a functioning vegetable garden, a student radio station, a school band, remedial classes in academic subjects, and study circles to prepare students to apply to the agricultural high school affiliated with the Autonomous University of Chapingo and its prestigious Agronomy School. These special clubs came about at the recommendation of school directors, since previously in the afternoons the boarding students often left the campus, graffitied the school, or experimented with drugs.

\footnotetext{
4 "Mexican middle schools are classified as either distance (telesecundarias), general (generales), or technical (técnicas). Technical middle schools have a subunit called specialized schools, focused on the unique setting in which the school is located. If the school is located in a rural area, it most likely will focus on agriculture and will offer technical subjects related to rural subsistence, as in the case of my technical middle school." (Personal communication from Mayem Arellanes Cano, Sept. 18, 2018).

${ }^{5} \mathrm{~A}$ movement led principally by university students which demanded democracy in the policies of the Mexican State. The students and other protesters were brutally oppressed, and some were assassinated or disappeared.
} 
There are 248 student boarders at the school, of whom 233 are males and 15 are females. Augmenting these numbers are 154 non-boarding day students, 86 males and 68 females. The day students receive classes along with boarders from 7:00 to 14:30 on school days, and then in the afternoons they return to their homes. All students are between the ages of 12 and 16. They come from different communities in 8 geographic regions of the State of Oaxaca, such as (but not limited to) Ozolotepec, Loxicha, Amoltepec, Güilá, and San Mateo del Mar. Their travel time from home to school ranges from 10 minutes to 10 hours.

In the past females have attended Technical Middle School \#14 only as day students, but for the first time in the 2018-2019 academic year, 15 females were accepted as boarders in a pilot program. So far, the presence of female boarding students has not raised any of the anticipated concerns. Instead, more parents have asked that their daughters be admitted, requesting additional spaces for females for the next academic year. We see changed social behavior in the male boarders since the girls arrived as boarders; whereas before boys would punch each other, or talk with their mouth full, or throw food scraps around in the cafeteria, now they are behaving more politely in the girls' presence. Boys even compete to be boyfriends with the few girls since the number of male boarders far exceeds that of females. Still, at first we did notice rejection of female boarders by some girl day students, who were overheard calling them "filthy" and "ugly," perhaps discriminating against those who come from more rural, impoverished communities.

Students who are boarders are only permitted to leave the school grounds on weekends. Some use this "free" time to return to their home communities, while others work in local communities cutting sugarcane, harvesting nuts, or hauling earth for gardens, anything to have a minimal income to help cover small expenses such as buying personal hygiene items. Other boarders who live further away only leave during school holidays.

Low income boarders receive government food scholarships. Each scholarship amounts to thirty pesos per day (about $\$ 1.55 \mathrm{US}$ ), which is supposed to cover the cost of three meals. Obviously, this government subsidy falls far short of what would be needed to provide three nutritious meals per day.

\section{Linguistic Realities of Middle School \#14 Reyes Mantecón Boarding School}

As of fall 2018, a quarter of the students (103) reported being bilingual in Spanish and one of 10 Indigenous languages or language variants. The number of speakers of each Indigenous language is: Valley Zapotec (24), Zapotec of the South Sierra (37), Zapotec of the North Sierra (1), Isthmus Zapotec (5), Mixe (13), Chinantec (2), Mixtec (18), Nahuatl (1), Mazatec (1), Ombeayiüts (1). The bilingual students' levels of proficiency in Spanish and the Indigenous language may vary from highly proficient to somewhat conversant. Few, if any, have had the opportunity to become literate in their original language. Even among those who are functionally bilingual, many are ashamed to admit or display their bilingual competence in their original language on school grounds, reflecting pervasive societal disparagement of Indigenous languages and their own internalized linguistic rejection. In addition, sixteen students report that they understand an Indigenous language but are not speakers. The remaining students (75 percent of total enrollment) report no Indigenous language competence and are assumed to be monolingual in Spanish.

There are 101 of us adults working at the boarding school, including 8 administrators, 16 teachers of academic subjects, 4 who teach in the technical areas, 4 medical personnel, 3 psychologists, 10 clerical personnel, and 56 other employees, distributed among kitchen help, agricultural workers, after-school club attendants, and 
security guards. Approximately half of the workers have been at the school for 30 years or more; others are the children of former teachers who worked for 30 years in this school, and still others, like myself, are new in the last one to five years. Some workers and administrators are themselves graduates of this school.

Both before and since the imposed federal education reforms, classroom instruction in this boarding school has been, and still is, only conducted in Spanish, despite the fact that 25 percent of the student population speaks an Indigenous language fluently as a first or second language. Things could be different - two teachers and two administrators speak an original language, three other teachers at least understand a language, and perhaps other employees are original language speakers. But no teacher uses an Indigenous language for classroom instruction, and rarely, if ever, have I heard adults address students on campus in an original language.

\section{Seismic Aftershocks and the School Structure}

Unlike the preschool in San Mateo del Mar, our school is outside the major earthquake region so it sustained only minor damages in the earthquakes of September 2017, such as cracks in the walls of some dormitories. Still, in 2018, the physical structure of the school was 80 years old. While some recent earthquake damage has been repaired, the aging school structure shows obvious wear and tear after decades of governmental inattention.

\section{Seismic Aftershocks of the Education Reforms}

In 2015, the governor of Oaxaca published a decree that erased all the contractual agreements between the state government and the combative and powerful teachers' union state affiliate, Section 22. One of the most egregious implications of this decree and of the federal education reforms of 2013 was the cancellation of professional development opportunities for teachers. Prior to the decree, teachers who had a BA but had not studied at a teachers' college could teach in an elementary school if they took courses at some branch of the National Pedagogical University. For middle school teachers, the requirement was to take courses at the Higher Education Normal School of Oaxaca or participate in approved professional development courses. Since the decree of 2015 in Oaxaca and the federal education reforms of 2013, any college graduate nationwide in any field who passes a standardized exam can be contracted to teach classes without any requirement that they study specialized pedagogical courses.

Another pedagogical implication of this reform for middle schools nationwide is a reduction in hours for courses in the Social Sciences and Natural Sciences. Very recently a curricular reform was approved for the school year 2018-2019 that would eliminate technical areas like agricultural sciences and animal husbandry, in addition to local state and regional studies. Instead, increased hours are required for artistic education and English, promoting an education focused on cheap labor, not professional skills. This latest curricular reform seeks to completely sever students from nature and their rural roots, which could result in students losing interest or motivation to continue their studies at the specialized Agricultural School of Chapingo, and even rejecting and devaluing the field labor of their own parents. Fortunately, in Oaxaca these contested subject matters have been retained through political, administrative and pedagogical resistance by the teachers of these subjects and by the political clout of our combative union affiliate, Section 22.

\section{Seismic Aftershocks and the Curriculum}


Throughout the 50 years since this school was founded as a mid-level boarding school, no effort has ever been made to create a proposal or project to capitalize on the linguistic diversity of the students; to the contrary, in my short time here I have observed with concern that youth are marginalized, even by their peers, when they speak an original language. In addition, the curriculum and instructional materials exclude and discriminate against students who are original language speakers.

For this reason, and because I teach the class on the history and cultures of the state of Oaxaca, one of the subjects the curricular reform intends to eliminate, I saw the urgent need to develop an alternative proposal that would work to strengthen both oral and literacy skills in the original languages and display the great diversity of linguistic and cultural gifts of the young students in this boarding school.

\section{Resolve and Resistance: Celebrating and promoting original languages}

In August 2018, as a new school year began, my commitment to celebrate and promote my students' original languages took shape. I developed a project that I call Your Language, My Language, Our Languages, the general objectives of which are to acknowledge, value and maintain the linguistic and cultural diversity of our students, and to promote learnings about the original languages of Oaxaca. My specific objectives for the project are the following:

- Raise consciousness about the importance of our original languages and promote their preservation;

- Strengthen the identity of the students at our boarding school;

- Work toward the inclusion and legal equality of persons who speak an original language;

- Promote equality without losing personal, linguistic and cultural identity;

- Promote other academic and recreational options for young students who speak an original language.

To accomplish these ends, I plan to engage in specific activities with my students, including but not limited to the following:

Each student will investigate the details of her family and community history to produce a personal linguistic and educational autobiography: The language backgrounds and community and educational lives of my students are varied and complex. I want them to educate me about themselves and their personal experiences with languages, and if they have been put down or shamed at home or at school for speaking their original language. To do this, I have asked them to respond in writing to questions such as: How many languages do you understand, or do you speak? How and from whom did you learn each one? With whom do you speak each language today? What languages were heard and used in your family during your childhood? Has that changed now in the present? Are there languages that have been lost in your family, languages that are no longer used or learned? If so, why? Regarding their home life: Where did you grow up? What responsibilities did you have at home? What did you do for pleasure and to relax? Regarding literacy: How many languages do you read and write? How did you learn to read and write Spanish? As a child, did you have books in your home? If so, in what language(s)? Who read books to you or told you stories? How much do you read in your daily life today? Do you read and write your original language, and if so, how did you learn to do that? Who taught you? Regarding their 
schooling: Where did you go to school? Were your schools bilingual? Were your teachers Indigenous? What language(s) did you use at school? ${ }^{6}$

My hope is that researching and documenting their language autobiographies will encourage my students to talk and reflect with their families and with each other, both in specific language groups and in mixed language groups; that they will feel affirmed and supported as they investigate and share their language histories; and that through experiences such as this my students will deepen their own cultural and linguistic identity.

A few weeks ago when our new school year began, the language autobiographies were the first task I assigned my students. We are still early in the project, but fragments of two student autobiographies give a taste of the thoughtful stories that are resulting:

Male Student \#1: I was born in Tlacolula de Matamoros, Oaxaca. My family is made up of my parents, myself and my sister. As a child I was responsible for cleaning the house, feeding the sheep, and hauling wood. I learned to wash dishes from my mom and to clean the cornfield with my dad. As a child I played football with my neighbor.

They took me to school when I was 2 years old. I cried, I felt very sad and had almost no friends. My companions didn't speak my original language, only their parents did. My teachers were Indigenous but they didn't talk to me in the original language. They treated me well and didn't scold me. My parents volunteered their labor at the school.

I speak Valley Zapotec, which I learned from my grandma. She taught me how I should say it. Today I speak Zapotec only at home with my grandpa, but I don't know how to write it. My parents can only understand Zapotec, they don't speak it, and when they respond to my grandma they do it in Spanish.

Male Student \#2: I was born in Huautla de Jiménez and I grew up in San Mateo Yoloxochitlán. My family is made up of my parents, a brother, three sisters and me. My responsibilities included sweeping my room. As a child I played with little cars in my house with my cousin and brother.

They took me to school at four years old. I was afraid to go to school. My preschool and elementary school were bilingual, my teachers were indigenous, they spoke to me in Mazatec and Spanish. My parents didn't participate at all at school.

My responsibilities were to haul wood, to sweep and to wash. I learned Mazatec from my mom and my grandma. Still to this day I speak Mazatec with my grandma. My mom spoke it with my grandma and I didn't understand that much. Our language has been lost in our community because everyone leaves for the city.

I also asked 62 parents of $7^{\text {th }}$ grade students to write their linguistic autobiographies, which included this question: Would you want your children to speak your original language? Of these, 56 parents responded clearly that they do want their children to learn their language. Seven parents gave ambiguous responses or didn't answer the question; still, not one parent responded "NO!" Two examples of parents' responses follow:

\footnotetext{
${ }^{6}$ This assignment was modeled on a task designed earlier by Lois Meyer to document the intergenerational linguistic and educational histories of Oaxacan teachers who participated in 2011-2012 in a Oaxaca State Institute of Public Education (IEEPO) accredited Diplomado in Community-based Initial Education (Meyer, 2016).
} 
- I don't want my son to lose our original language, since we love how it sounds though it is not very useful outside our community, but he didn't want to learn it.

- I want my son to speak our original language because those who speak our mother tongue are given priority in our community once they are (adult) citizens of the community.

My goal is to edit a book of these student and parent autobiographies to use as an instructional material in my classes and to share with other instructors. Inspired by their own life stories, I want my students to talk and reflect together about their home and community cultural practices, language learning, language loss and its causes in their family and community, and especially about the role of schools in that ethnocentric process. I also want them to consider their parents' hopes for their future and the future of their original language. My hope is that in this way we can create a space where students feel proud about who they are as Indigenous language speakers, and that together we promote other opportunities at our school where this pride can be nurtured and expressed.

Already other ideas for activities have been proposed:

- Create linguistic maps of the students' communities, displaying in which community context they speak each of their languages;

- Paint murals on our school walls using phrases in Indigenous languages;

- Tape record legends and recipes in original languages told by parents and grandparents, and then investigate, even create, the alphabets to transcribe them;

- Carry out physical exercises, such as dancing or cooking, and learn how to talk about these activities in different original languages;

- Research and display the history of their community by means of a timeline and locate illustrations of important events and people on the timeline;

- Exchange visits with bilingual teachers and students from other schools;

- Have students create simple storybooks and instructional materials to teach the original language to preschool students in their home community. ${ }^{7}$

\section{Political Earthquake}

With the election of AMLO, personally I hope for greater institutional openness so that in schools we are free to develop and strengthen this kind of project. But this will only be possible if civic and teacher union pressure is applied, since the government will not change on its own. This is especially true now, given the relentless pressure on AMLO's incoming government that is being exerted by business interests that want to privatize education, benefitting only themselves. For this reason, it is imperative that we teachers continue the CNTE teachers' union time-tested strategy of struggle, that is, mobilize-then negotiate-then mobilize again.

\section{Teacher Resolve and Resistance}

Lois: We offer these case studies of Vicente Guerrero Bilingual Preschool and Reyes Mantecón Boarding School as two examples of the diverse ways in which Indigenous

\footnotetext{
${ }^{7}$ This idea was sparked by a pedagogical collaboration between high school students and preschoolers in the Vicente Guerrero Bilingual Preschool in San Mateo del Mar.
} 
teachers in Oaxaca are responding with resolve and resistance to the continuing seismic aftershocks of devastating geological earthquakes and tumultuous political and educational upheavals in their lives and work, all challenges that are beyond their control. Still, these teachers are not solitary or super-human heroines; rather, they resolutely join together with parents, students, community elders and authorities, academics, and their teachers' union to defend their collective language and culture rights and to initiate creative ways within their schools and their teaching practice to expand and strengthen the use of original languages in their students' lives today and for the future.

Personal narratives such as these, drafted in their own words by local Indigenous teachers outside the English-speaking Western world who recount the passionate commitment of their schools and communities to maintain and revitalize their original languages and cultures seldom appear in international academic journals published in English. Consequently, the resistance and resolve of Oaxacan teachers such as these to achieve community control over their linguistic and cultural futures despite seemingly overwhelming environmental, political and educational pressures are largely unknown to English speaking Indigenous and international educators. Beatriz, Gisela and Mayem are not unique - throughout the Americas, and indeed throughout the world, Indigenous teachers and communities struggle with passion to defend their ways of life into their future generations. What is perhaps unique here is that international readers are able to witness the courage and resilience of these teachers who are not academics or English speakers because the Spanish-English "language divide" (Meyer, 2010) has been bridged through translation.

We are honored to conclude with a word of reflection and encouragement offered by Native American educator Hayes Lewis. Our hope is that Hayes's words might encourage other international educators to reflect on, celebrate, and be inspired by the Oaxacan experiences of resistance and resilience documented here. We also hope that other accounts of the courageous, creative "lived work" of maintaining and defending original languages and cultures carried out tenaciously by Indigenous teachers and communities worldwide will be brought into the international literature through translation, to instruct and inspire us all.

Commentary (Hayes Lewis, Zuni elder, educator and activist, and former Superintendent, Zuni Public School District)

I am honored and humbled to have been asked to comment on the case studies shared by Beatriz Gutiérrez Luís, Gisela Baloes Gutiérrez, and Mayem Arellanes Cano, and developed and translated by Lois Meyer. This important article describes conditions and actions which honor ancestral perspectives and knowledge through resilience, strength and tenacity inherent among Indigenous peoples as represented by communal responsibilities and leader advocacy since time immemorial.

Seismic aftershocks is an apt metaphor for the many recent state-sponsored legislative and politically inspired laws and policies by governments throughout the Western hemisphere which have severely disrupted and challenged the human rights of Indigenous peoples and threatened their communal resources and the natural environment, while producing a destabilizing impact on the social, cultural and self-governance aspirations of Indigenous communities.

The recent massive restructuring of public education in Mexico and the so-called reforms do not recognize the multilingual and multicultural heritage of the country. The politically imposed standards of education impacting rural communities are a thinly veiled 
manipulation by the government to continue policies which serve to extinguish the cultural, educational and human rights of Indigenous peoples while using these policies and laws to expedite a system of cultural genocide and resource exploitation designed to eliminate the "Indigenous problem." This is reminiscent of the politically imposed policies undertaken by the United States government to dispossess North American Indigenous tribes of their ancestral lands, cultures, spiritual practices and resources.

A first step in such a process is removal of Indigenous peoples from ancestral lands, then the separation of the children from their culture, communities, linguistic heritage and important relationships. The educational reforms and related policies of Mexico are designed to eliminate the connections between Indigenous peoples and their lands, disrupt communal relationships, eliminate cultural identity and exploit their natural resources. This intentional and systematic form of cultural genocide has persistently continued in Mexico since the "great interruption" of human development on this continent by Spanish Europeans in the early 1500's.

\section{San Mateo del Mar: Vicente Guerrero Bilingual Preschool}

The seismic aftershocks of the earthquakes of September 2017 and the political aftershocks of the imposed educational reforms have severely disrupted the communal education initiatives in rural communities of Oaxaca. In spite of this, communal educators such as Beatriz and Gisela at the San Mateo del Mar bilingual preschool have actively worked to coordinate communal efforts to maintain linguistic and holistic forms of cultural education for children in the face of natural disasters, unrealized government promises, and abandonment.

The incorporation of the ancestral environment, natural resources, climate studies, plants, ocean life, traditional games, and the daily lives of parents, relatives and families represents culturally authentic ways of teaching and learning. Important relationships, the natural world, ancestral knowledge and use of the Ombeayiüts language reinforce Indigenous identity through play and practice. The descriptions of earthquake trauma in the lives of children and families as narrated by the children were evidence of an indelible and terrifying experience, but one that also reinforced Ombeayiüts language usage in many unanticipated and profound ways. Many educators in the U. S. are now considering holistic approaches to teaching and learning through "new" methodologies such as Project Based Learning, while the Ikoots teachers' holistic practices are based on ancestral ways of teaching and learning which have stood the test of time and function.

\section{San Bartolo Coyotepec: Reyes Mantecón Boarding School-Technical Middle School \#14:}

The seismic aftershocks represented by constitutional reform and massive governmental restructuring of public educational policies and practices have led to the closing of thousands of rural schools in Mexico. Mayem is a Zapotec lawyer and also a teacher of the history and cultures of the state of Oaxaca at Reyes Mantecón Boarding School.

Mayem provides an excellent overview of the context of educational conditions and the demographics of students and workers at the school. She notes that since the school was founded over 50 years ago as a mid-level boarding school, no efforts have been made to recognize the linguistic or cultural diversity of the staff or the students, and those who speak an Indigenous language are ashamed of their linguistic heritage and/or are ridiculed by peers. The result is a system of education that rejects ancestral knowledge, minimizes 
the value of Indigenous languages and cultures, and fosters disconnect between children, communities and cultural relationships. Such an extreme educational environment is directly attributable to governmental reforms and educational policies that foster the elimination of language and culture as an expedient means to create a homogenizing, onesize-fits-all system of education.

In spite of this, Mayem is fully committed to teaching her students about the Indigenous cultures of Oaxaca and is working to foster a sense of pride in their Indigenous heritage. However, she has a particularly challenging assignment because the official language of instruction is Spanish. In order to promote language, culture and identity, she is developing an alternative curriculum and course of study to strengthen the oral and literacy skills of the boarding students in their original languages. Her project, entitled Your Language, My Language, Our Languages, acknowledges the linguistic and cultural diversity of her students and promotes the learning of the original languages of Oaxaca. Her intent to promote a stronger cultural context to support her students is based on specific objectives and activities that recognize and honor the richness of the cultural diversity represented at the school.

The courageous actions by these authors support community members, other teachers and children to recover from devastating natural disasters and the seismic disruptions of either government inaction or repressive and imposed educational policies. The strength, courage and commitment to language, culture and community exemplified by Beatriz, Gisela, and Mayem serve as models of courage, resilience and inspiration to Indigenous educators and all educators and activists worldwide.

\section{References}

Garfinkel, H. (1967). Studies in Ethnomethodology. Englewood Cliffs, NJ: Prentice-Hall. Paperback edition (1984): Studies in Ethnomethodology. Cambridge, United Kingdom: Polity Press.

Garfinkel, H. (2002). Ethnomethodology's Program. Lanham, MD: Rowman \& Littlefield. Granja Castro, J. (2010). Procesos de escolarización en los inicios del siglo XX: La instrucción rudimentaria en México. Perfiles educativos, 32(129), México. Retrieved from http://www.scielo.org.mx/scielo.php?script=sci_arttext\&pid=SO 185$\underline{26982010000300005}$

Heritage, J. (1984). Garfinkel $\mathscr{E}^{2}$ Ethnomethodology. Cambridge, United Kingdom: Polity Press \& Blackwell Publishers Ltd. Reprinted (2004). Garfinkel \& Ethnomethodology. Cambridge, MA: Blackwell Publishers.

Hernández Navarro, L. (2016, December 6). La guerra contra las escuelas multigrado. La Jornada. Retrieved from https://www.jornada.com.mx/2016/12/06/opinion/o20a2pol

Ignacio, L. (2017, October 7). 7 de septiembre, el día del desastre de Oaxaca. Noticias: Voz $e$ Imagen de Oaxaca. Retrieved from https://www.nvinoticias.com/nota/72498/7-deseptiembre-el-dia-del-desastre-de-oaxaca

Instituto Nacional de Lenguas Indígenas. (2012). Lenguas indígenas nacionales en riesgo de desaparición: Variantes linguïsticas por grado de riesgo. A. Embriz Osorio \& O. Zamora Alarcón (Coords). México, D.F.: Instituto Nacional de Lenguas Indígenas (INALI). 
Kelly, J. (1994). Article 27 and Mexican land reform: Legacy of Zapata's dream. Columbia Human Rights Legal Review 541 (1993-1994). Retrieved from https://scholarship.law.nd.edu/law_faculty_scholarship/668

Mandujano, I. (2018, July 6). El EZLN pone distancia con AMLO: Podrá cambiar el capataz, pero el finquero sigue siendo el mismo. Proceso online. Retrieved from https://www.proceso.com.mx/541872/el-ezln-pone-distancia-con-amlo-podracambiar-el-capataz-pero-el-finquero-sigue-siendo-el-mismo

Meyer, L.M. (2010). A hemispheric conversation among equals. In L. Meyer \& B. Maldonado Alvarado (Eds.). New World of Indigenous Resistance: Noam Chomsky \& Voices from North, South, and Central America (pp. 7-37). San Francisco, CA: City Lights Publishers.

Meyer, L.M. (2017). Resisting Westernization and school reforms: Two sides to the struggle to communalize developmentally appropriate initial education in Oaxaca, Mexico. Global Education Review, 4. (3), 88-107. Retrieved from http://ger.mercy.edu/index.php/ger/article/view/351

Meyer, L.M. (2016). Teaching our own babies: Teachers' life journeys into communitybased initial education in indigenous Oaxaca, Mexico. Global Education Review, 3(1), 5-26. Retrieved from https://pdfs.semanticscholar.org/eec7/f4e2576308e97e7bbf29444b729b457e2399.p df?_ga=2.36184229.462467434.1571171587-1671685680.1571171587

Mioli, T. \& Higuera, S. (2016, June 3). Mexico allows broadcasts in Indigenous languages following reform of the telecommunications law. Journalism in the Americas.

Retrieved from https://knightcenter.utexas.edu>Home>

Para reconsiderar la estrategia "reconcentración de escuela" planteada por la SEP. (2016). Revista Latinoamericana de Estudios Educativos (México)[on line], XLVI(4), 5-10. Retrieved from http://www.redalyc.org/articulo.oa?id=27049500001

Partlow, J. (2018, July 2). López Obrador wins Mexican presidency, becoming first leftist to govern in decades. Washington Post online. Retrieved from

https://www.washingtonpost.com/world/mexicans-head-to-polls-to-choose-a-newpresident/2018/07/01/517e86707a2a11e8ac4e421ef7165923_story.html?utm_term $=.2 \mathrm{bb} 834 \mathrm{~b} 49 \mathrm{do} 8$

Programa del Movimiento Regeneración Nacional, (n.d.) ¿Por qué luchamos? \#5: Por una nación pluricultural y el respeto a los pueblos indígenas. Retrieved from https://lopezobrador.org.mx/programa-del-movimiento-regenarcion-nacional/

Rockwell, E. \& Garay-Molina, C. (2014). Las escuelas unitarias en México en perspectiva historica: Un reto aún vigente. Revista Mexicana de Historia de la Educación, II(3), 124. Retrieved from http://www.rmhe.somehide.org/index.php/revista/article/view/33

Schoenhals, L. (1964). Mexico experiments in rural and primary education: 1921-1930. The Hispanic American Historical Review, 44(1), 22-43. Retrieved from https://www.jstor.org/stable/2511122?seq=1\#metadata_info_tab_contents

Snyder, Michael. (2017, November 13). After the quake. Slate. Retrieved from http://www.slate.com/articles/news_and_politics/roads/2017/11/istmo_de_tehua ntepec_southern_mexico_is_still_reeling_from_september_s_earthquake.html

Soberanes Bojórquez, F. (2017, March 24). La desaparición de 100 mil escuelas. Unpublished analysis cited with permission of the author. 
Vázquez Carranza, A. (2009). Linguistic rights in Mexico. Revista Electrónica de Lingüística Aplicada, 8, 199-2 10. Retrieved from http://www.academia.edu/998641/Linguistic_Rights_in_Mexico

Wood, D., Rios, V., Wilson, C., Schmidtke, R., Olson, E. \& Wayne, E.A. (2018, July 20). Changing the guard in Mexico: AMLO's opportunities and challenges. Mexico Institute: Wilson Center. Retrieved from https://www.wilsoncenter.org/publication/changing-the-guard-mexico-amlosopportunities-and-challenges

\section{About the Authors}

Beatriz Gutiérrez Luís is the last of 10 siblings and a native of San Mateo del Mar in the Isthmus of Tehuantepec, Oaxaca, Mexico. Beatriz, a bilingual preschool teacher presently working with 4-year-olds, is a member of the Coalition of Indigenous Teachers and Promoters of Oaxaca (CMPIO) and also a member of Oaxaca's powerful state union affiliate, Section 22. For 24 years she has worked to promote the guiding principles of CMPIO's Pedagogical Movement, especially the defense of Indigenous languages and cultures. Together with their community, her school has worked to create an alphabet to write their Ombeayiüts language and produce books and other teaching materials for use in their bilingual program. For 30 years she has participated in two communal assemblies, one where community authorities are elected, and in the agrarian assembly; the assemblies fight to defend their territory, their language and their culture. Since the destructive earthquakes of 2017, Beatriz volunteers in the reconstruction of her community, promoting the use of traditional architecture, and she participates in a cooperative of women that forms part of the communal organization MONAPAKÜY (strength, life force, health, good life).

Gisela Baloes Gutiérrez is a native of the Ikoots community of San Mateo del Mar, Oaxaca. She is a speaker of the Ombeayiüts language and a teacher in her community's Indigenous bilingual preschool. In her teaching she separates the two languages, Spanish and Ombeayiüts, to encourage full development of each, and she strengthens her curriculum with community-based themes, such as Ikoots descriptions of flavors, smells, shapes, sizes, and local fruits, in this way reinforcing the children's identity at an early age. Gisela works closely with the children, parents and her colleague teachers to stress the importance of community involvement in education. She belongs to the Coalition of Indigenous Teachers and Promoters of Oaxaca, and also is part of the state union affiliate, Section 22. Gisela also belongs to a community organization called MONAPAKÜY, contributing her unpaid labor to this coordinated and organized effort of women in support of the families who suffered terrible losses after the earthquake. Love of her work and her community are what motivate her day after day to create a quality bilingual education appropriate for her surrounding community context.

Mayem Arellanes Cano is a Zapotec lawyer, human rights defender, and Social Sciences middle school teacher born in Ejutla de Crespo, Oaxaca. Her legal experience is extensive: lawyer to the November 25 Liberation Committee created by the painter Francisco Toledo to defend political prisoners of the Popular Assembly of the Pueblos of Oaxaca (APPO) after the teacher-civic popular rebellion of 2006 in Oaxaca; collaborator with the National Study against Feminicide; and lawyer in the Secretary of Judicial Affairs of the teachers' union affiliate, Section 22-SNTE-CNTE. Mayem was a member of the commission tasked with drafting a Citizens' Initiative for a new Education Law for the State of Oaxaca. She has defended victims of forced disappearance and those assassinated by police forces in Nochixtlán, Oaxaca, in 2016. Mayem has also collaborated in the defense 
of the rights of teachers negatively impacted by punitive education reforms. She has been an invited presenter to legal and activist teacher groups in Mexico, as well as in Texas, Arizona, New Mexico, New York, Pennsylvania, and Illinois. Mayem presently serves as a legal advisor to the LXIV Legislature of the Mexican Congress.

Lois M. Meyer is Professor of Bilingual and Second Language Education and Qualitative Research in the Department of Language, Literacy \& Sociocultural Studies at the University of New Mexico in Albuquerque. Her PhD. from UCLA is in Applied Linguistics with specialties in Second Language Acquisition and Language Education. Lois has lived for 14 years in Latin America, where she taught English as a Foreign Language to children in a large bilingual school and coordinated language instruction programs. For 20 years she has collaborated closely with Plan Piloto-CMPIO, a coalition of 1200 Indigenous teachers in Oaxaca MX on professional development and community-based action research, beginning with a Fulbright Senior Researcher award in 1999-2000. Since that time, she and her Indigenous colleagues have co-authored and published articles and books internationally in both English and Spanish, and also co-presented at conferences in the US and Latin America. Priority concerns of their work are Indigenous language and culture maintenance and revitalization and Indigenous community-based educational autonomy. 